POLIIICAL ECONOMY RESEARCH INSIITUTE

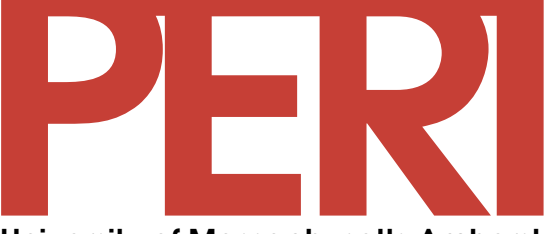

University of Massachusetts Amherst

\title{
Global Labor Standards: their impact and implementation
}

\author{
James Heintz
}

2002

10th floor Thompson Hall University of Massachusetts Amherst, MA, 01003-7510 Telephone: (413) 545-6355 Facsimile: (413) 545-2921

Email:peri@econs.umass.edu Website:

http://www.umass.edu/peri/

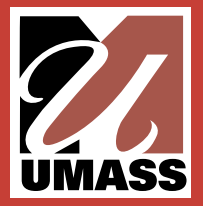




\title{
Global Labor Standards: their impact and implementation
}

\author{
James Heintz \\ Political Economy Research Institute \\ University of Massachusetts \\ jheintz@econs.umass.edu \\ November 2002
}

JEL Classification: F02, J8, J23, O17

Key words: labor standards, global integration, employment, gender, codes of conduct

This working paper represents a somewhat longer version of a book chapter prepared for Jonathan Michie, ed. The Handbook of Globalization, Edward Elgar, forthcoming 2003. The author would like to thank Gerald Epstein and Robert Pollin for helpful discussions, suggestions, and comments. Furthermore, the participants attending the meeting of a working group on Global Labor Standards and Living Wages, April 19-20, 2002, at the Political Economy Research Institute of the University of Massachusetts, constituted a rich source of ideas and opinions that informed this paper. 


\begin{abstract}
This paper reviews the critical issues concerning the establishment of a global system of labor standards. Global labor standards have gained a renewed prominence in policy debates with the rise of the new international division of labor, in which developing countries are producing an ever-increasing share of the world's manufactured exports. This paper takes a close look at the research and theories that inform the current debates. In particular, it summarizes the arguments in support of global standards, evaluates the threat of unintended negative consequences, examines gender-specific issues relating to low-wage labor and informal employment, and discusses past and present developments in implementation strategies.
\end{abstract}

\title{
Introduction
}

Over the past four decades, a fundamental restructuring of international production has taken place, a transformation which is frequently referred to as the "new international division of labor". Developing countries have been shifting from exporting primary goods and raw materials to also exporting manufactured goods and intermediate inputs. The expansion of manufactured exports from the developing world has unleashed new competitive pressures. Not only are the newly industrializing economies competing with more established industrial powers, they also compete with each other. In this environment of heightened competition, individual countries acting alone find it increasingly difficult to sustain social protections that raise factor prices - most notably wages and other payments to labor. As these trends have become more pronounced, international concern over fundamental human rights at work, the payment of poverty wages, and the existence of dangerous working conditions has intensified.

Recent evidence shows that, in the developing world, approximately 25 percent of people engaged in paid labor live in households that survive on less than the equivalent of US\$1 per person, per day (Majid 2001). Moreover, setting a more accurate poverty line for these countries would raise this estimate of the working poor population significantly (Reddy and Pogge 2002). The widespread incidence of poverty wages among working people around the world today is indicative of a more general prevalence of unhealthy, dangerous, and indecent working conditions. In recent years, calls for a coordinated system of global labor standards have gained strength in order to address the problem. The following paper takes a close look at the debates surrounding global labor standards. In particular, it summarizes the key arguments in support of global labor standards, evaluates the threat of negative consequences that could spring from such regulations, and discusses current developments in implementation strategies.

\section{The labor standards debate: a summary of the key issues}

One of the most prevalent arguments as to why a coordinated approach to global labor standards is necessary is that it prevents a "race to the bottom". That is, upward 
harmonization of standards stops competitive pressures from reducing labor protections to their lowest common denominator. According to this logic, global integration creates a situation in which the deterioration of basic standards is rewarded by increased competitiveness and profitability. In the absence of international cooperation, individual countries cannot raise labor standards without jeopardizing their competitive advantage. The scenario represents the typical prisoner's dilemma problem - countries will adopt the same low standards, even if social welfare falls below its potential maximum. Because of this, competitive advantages derived from weak labor standards are frequently seen as "unfair" competition, since international cooperation in the form of global standards could produce a better outcome (Sengenberger 1994).

The suboptimal outcomes associated with a race to the bottom occur because the competitive erosion of labor standards generates external costs that reduce social wellbeing. These negative externalities can arise when individuals and their labor are treated as any other commodity to be exchanged on unregulated markets. ${ }^{1}$ The notion that labor should not be subjected to the unfettered machinations of a liberal market economy has given theoretical life by economic thinkers such as Marx and Polanyi. For example, Marx warned that the commodification of labor would lead to the alienation of the working population from the functioning of the economy, with substantial human and social costs. Similarly, Polanyi (1944) argued that subjecting labor to unregulated market forces would generate external costs - including health problems, a deterioration of family and community structures, an erosion of craft standards, and a general degradation of many aspects of public and private life. According to Polanyi (1944, 1957), labor markets should be embedded in the larger society and must be governed by rules, norms, and ethical standards that make allowance for the hidden costs of marketization.

In addition to arguing that labor standards protect valuable non-market aspects of society, some proponents have justified them in terms of economic efficiency (Palley, Drake, and Lee 1999, Buchele and Christensen 1995). According to this line of reasoning, labor standards support better labor relations, cooperation on the job, and sharing of information - factors which would enhance productivity. In addition, better standards, including higher wages, could pay for themselves through efficiency wage effects that increase effort on the job (Goldstein, Veum, and Darity 2000, Huang et al. 1998, Levine 1992, Shapiro and Stiglitz 1984). However, additional empirical research is needed to document whether and under what conditions higher standards will exhibit these benefits in an international context.

Moreover, there is a theoretical problem with this argument: if higher standards are profitable, then why do employers fail to adopt them? One answer is that multiple equilibria exist and employers fall into low-wage, low-productivity traps. A policy intervention is necessary to move the labor market onto the high-road of greater efficiency. Alternatively, substandard employment might arise from a focus on short-term gains while ignoring long-term dynamic efficiencies. For example, the use of child labor could maximize short-term profits despite the low productivity of the very young.

1 The International Labor Organization (ILO) adopted the stance that labor was not a commodity in its 1946 Declaration of Philadelphia. The Declaration was attached as an appendix to the ILO constitution. 
However, keeping children out of school could be inefficient in the long-run since it means foregoing the future benefits of greater accumulation of human capital and higher productivity (Basu 1999). Finally, the productivity-enhancing effects of higher wages can extend beyond the point of profit maximization. That is, additional productivity gains can be achieved through higher wages even though individual firms do not have an incentive to pay the larger premium.

Labor standards could also produce faster growth due to their macroeconomic, not microeconomic, impact. A coordinated system of standards that increase labor's bargaining power will redistribute income towards workers. Higher labor incomes could raise global demand and yield faster growth (Marshall 1994). This is particularly likely to be true for economies whose institutional setting and complementary economic policies support a regime of "wage-led growth", in which higher domestic wages are able to raise aggregate demand (Stanford 1998). Others have reversed the logic and argued that more expansionary macroeconomic policies will produce an environment conducive to improving international labor standards (Singh and Zammit 2000, Amsden 1994). In this case, faster growth raises labor standards, not vice versa.

The arguments in favor of a system of global standards must be evaluated against warnings as to the potential dangers. In general, most arguments against global labor standards claim they will trigger unintended consequences that will end up hurting the very people the policies aim to help. For example, eliminating child labor could encourage child prostitution. Raising wages could cost jobs. Stricter enforcement could cause firms to relocate. In short, global labor standards create market distortions that reduce economic well-being due to an inefficient allocation of resources.

The most common variant of this theme is the argument that global standards compromise the competitive position of those developing countries with an abundance of low-skill, low-wage labor (Bhagwati 1995, Corden and Vousden 2001). This loss of competitive advantage means fewer jobs and scarcer economic opportunities for poor workers with few skills. On the flip side, such protections shield workers in more affluent economies from global competition. In effect, there is a redistribution of wage income from developing to developed economies. Because of this, organizations advocating for better labor standards on a global scale have been accused of pushing an agenda of disguised protectionism (Bhagwati 2002: 47-90). Others have emphasized the relative importance of job opportunities over job quality for poor families in developing countries (Krugman 1998, Kristof 2002). They argue that, in the stark reality of the global economy, poverty-level wages and substandard employment represent an improvement over the next-best options in labor-surplus economies.

Others advance the position that, with complete markets, no externalities, and costlessly enforceable contracts, global labor standards will create a dead-weight welfare loss (Brown, Deardorff, and Stern 1996). However, this efficiency argument depends on perfect markets being able to seamlessly map shifts in relative factor prices onto the output prices of tradable goods and services in order to achieve Pareto optimal outcomes. 
The introduction of market imperfections, externalities, or multiple equilibria dramatically changes this picture.

The idea that higher labor incomes support growth at the macroeconomic level has also been questioned. In the case of a small open economy, it is not always clear that a redistribution of income towards labor creates higher levels of aggregate demand (Bowles and Boyer 1995). Wage income can be leaky in an economy with a strong propensity to import. Furthermore, insofar as investment responds positively to profitability, then standards that raise labor costs could have a dampening effect on investment, aggregate demand, and ultimately growth. Of course, if standards were enforced internationally, then global aggregate demand would rise as standards improve. However, small, open economies that compete for external sources of aggregate demand might still be characterized as profit-led, since higher unit labor costs undermine their ability to sell on global markets (Amsden 1997).

Finally, there are non-economic considerations that should be taken into account in particular, the political process by which the standards are developed. If the movement for global standards is primarily an outcome of concerns raised only by advanced industrialized economies, then the justification for these standards to be foisted upon developing nations becomes questionable, particularly if such standards are not considered to be part of the body of commonly accepted international law. Under these conditions, charges of "aggressive unilateralism" and "disguised protectionism" carry additional weight (Alston 1996). Similar concerns surface in proposals that delegate responsibility for labor standards to global governance institutions (e.g. the World Bank or the World Trade Organization) in which the balance of power tilts in favor of the world's rich countries.

\section{Gender dynamics and informalization}

With the new international division of labor, women frequently account for the majority of the labor in low-income sectors producing manufactured exports. Lower wages for women have supported demand for their labor in highly mobile, laborintensive industries. These developments have been linked to a reduction in average job quality that has accompanied a growth in women's labor force participation - a phenomenon that has been termed "global feminization" (Standing 1989). However, it is also important to recognize that, since labor markets around the globe remain segregated by gender, the growth in women's share of low-wage employment also results from an expansion of jobs typically dominated by women, not simply an erosion of the quality of existing jobs as women enter the labor force (Elson 1996). At first blush, the existence of a high proportion of women working in global manufacturing industries might imply that women would be the primary beneficiaries of improvements in labor standards. Such a cursory analysis, however, ignores the position women frequently occupy in both the household and in the paid labor market. 
While the employment of women keeps labor costs low and enhances a firm's profitability, low-wage jobs also provide economic opportunities for women outside of the household and, in turn, can grant them a greater degree of choice in their lives (Kabeer 2000). This enhanced freedom gives women the latitude to delay marriage and childbearing, gain labor market experience, protect their economic options outside of the household, and increase their long-run earnings potential (Lim 1983). Furthermore, access to money income improves women's bargaining position at home, thereby affecting gender dynamics and strengthening women's influence over the distribution of household resources (Braunstein 2002, Sen 1990, Roldan 1988, Joekes 1987). Therefore, insofar as better standards reduce employment, these job losses disproportionately affect women, directly through a loss of wage income, but also indirectly by exacerbating other gender-specific inequalities. Even if the number of jobs remains unchanged, better employment conditions can impact women's access to jobs. For example, there is evidence that as job quality improves, women's access to these opportunities declines relative to men's (Elson 1996).

However, others have questioned the optimistic claim that low-wage employment provides an impetus for improvements in gender equality. Since women are often employed in globally mobile industries, an expansion of employment in these sectors may not raise women's bargaining power relative to men working in less footloose sectors, especially during periods of economic liberalization (Seguino 2001). Along similar lines, a recent survey of women working in the maquiladoras of Tijuana found that the expansion of jobs had little impact on their ability to demand higher wages. The workers' income was not significantly higher than what they could earn elsewhere, although maquila earnings were more stable (Fussell 2001). Survey work in Pakistan suggests that the availability of subcontracted work does not improve the autonomy of women workers when such work reinforces their marginal position in the economy. Furthermore, participation in the subcontracted labor market in Pakistan is often the result of the "push" of poverty, rather than the "pull" of securing an independent income (Khattak 2002).

The question of global labor standards, worker welfare, and gender dynamics becomes more complex when we consider the growing informalization of the low-wage labor market. Informalization refers to the process by which economic activities increasingly move into unregulated spheres. Informalization manifests itself in numerous ways: a growth of the informal economy relative to the formal sector; an expansion of temporary, contingent, and marginal jobs; an increase in the incidence of outwork (e.g. home-based production); and a lack of adequate enforcement for existing regulations. In this respect, informalization reflects the erosion of job quality and the expansion of flexible employment practices that has become a defining feature of the current patterns of global integration (Standing 1999).

Recent research has documented a world-wide resurgence of informalization beginning in the 1970s and continuing into the 1980s and 1990s (ILO 2002, Benería 2001, Charmes 2000, Portes et al. 1989). The fact that many countries have seen informal employment expand during periods of relatively stable growth supports the argument that 
structural changes in the global economy are responsible for growing informalization. This stands in contrast to earlier cyclical explanations that saw a rise in informal employment as being directly tied to poor economic performance in the formal sector.

Informalization impacts labor standards through two channels. By definition, informalization increases the share of workers who are not covered by existing regulations. More indirectly, an expansion of the informal sector can place downward pressure on standards in formal employment by weakening the bargaining power of formal sector workers. A general erosion of labor standards will be most pronounced when workers face a compromised fallback position. Since the supply price of labor for formal sector occupations depends, in part, on the income that could be earned elsewhere, patterns of informalization which reduce the average quality of economic alternatives will increase the vulnerability of employment conditions in many entry-level, formal sector jobs.

In most countries, women account for the majority of informal sector workers (Benería 2001). Therefore, the process of informalization parallels the general expansion of low-wage employment for women. In addition, many informal sector workers face constraints that bar their participation in the formal labor market. For example, women engaged in childcare and other forms of unpaid household labor might be unable to participate in formal sector labor markets if the available jobs conflicted with patriarchal norms, the ability to perform unpaid work, or the quality of caring labor at home. ${ }^{2}$ In such cases, informal employment offers greater flexibility. Furthermore, there is some evidence that more austere macroeconomic policies, such as those associated with structural adjustment programs, have squeezed household resources and reduced the number of formal sector jobs. These conditions create an incentive for greater participation in informal productive activities in order to maintain household incomes (ILO 2002, Benería 1991, Vandemoortele 1991).

Informal employment poses important challenges for enforcing global labor standards. The unregulated nature of informal production reduces labor costs and gives the informal economy a competitive edge over formal employment arrangements. Raising standards in the formal sector, therefore, could displace economic activity into the informal sector. Indeed, the recent growth of the informal sector calls into question the effectiveness a purely legislative approach towards improving employment conditions since existing labor protections are not enforced in the informal sector. A more effective strategy would improve employment conditions in the formal and informal sectors simultaneously. This would require a partial "formalization" of informal sector activity. However, reversing the process of informalization has the potential of negatively impacting women's access to an independent source of income. This would occur if formal sector jobs are disproportionately held by men, due either to labor supply constraints or patterns of labor market segmentation.

2 For example, Sathar and Kazi (1989) found that Pakistani households in which women worked in more formal factory settings had a higher incidence of child mortality than households in which women were engaged in paid home-base production. 


\section{Damned if you do: evaluating the risk of unintended consequences}

Perhaps the strongest caution against global labor standards is the danger of job loss, particularly in developing countries with an abundance of low-wage labor and few alternative opportunities. This concern about jobs is not trivial. The International Labor Organization estimates that at the end of 2000, approximately 160 million people will be unemployed around the world (ILO 2001: 15-23). Furthermore, the argument that global labor standards will exacerbate gender inequalities is largely based on concerns that disemployment effects will hit women the hardest.

Labor standards reduce employment when they raise the cost of labor. Obviously, new standards will have no impact on employment if current practices already fulfill all the regulatory stipulations. Nevertheless, improvements in standards are justified precisely because existing conditions generally fall below a perceived threshold of decency. Therefore, if global labor standards are designed to have a broad social impact, they will likely raise labor costs. Indeed, empirical studies have shown a correlation between better labor standards and higher labor costs (Rodrik 1996). However, even when standards raise the cost of labor, these higher costs do not automatically translate into a substantial loss of jobs. The question of the connection between labor costs and jobs remains an empirical one.

In evaluating the possibility that better standards mean fewer jobs, we begin with a more focused question: have low-wage countries experienced faster rates of employment growth in labor-intensive manufacturing than high-wage countries? In answering this question, it is simplest to restrict attention to one sector: the manufacture of clothing and wearing apparel. Why clothing? First, clothing is a highly globalized, labor-intensive industry. Labor costs make up a large fraction of production costs and competitive pressures are fierce. Second, debates over global labor practices often center on clothing firms. For these reasons, clothing is a particularly relevant industry for this discussion.

A note of caution is warranted when approaching international statistics on global production. In most economies around the world, some production occurs in places other than a formal factory setting. Clandestine workshops, sizeable informal economies, and home-based manufacturing are often located outside of the world of formal regulations and official statistics. In these cases, official data will frequently fail to capture the details of these informal economies. Nevertheless, with this important caveat in mind, examining the available evidence does provide us with a clearer idea of the relationship between the costs of labor and employment. ${ }^{3}$

Figure 1 plots the initial level of apparel wages, expressed in U.S. dollars, against subsequent employment growth, expressed as the average annual growth rate, for 59

\footnotetext{
3 The existence of informal production that could, at relatively low cost, substitute for formal production would tend to increase the observed responsiveness of employment to labor costs in the formal sector since labor could be displaced into the informal sector.
} 
countries for which comparable data are available. ${ }^{4}$ The initial wage level is measured as a three-year average, centered on 1982, in order to smooth the distortions that could be introduced by exchange rate fluctuations in any given year. Employment growth reflects the 15-year period, 1982 to 1996 . The figure shows a clear negative relationship between initial wage levels and subsequent employment growth. The estimated regression line running through the observations has a statistically significant negative slope (p-value $<$ 0.0001 ) - every additional $\$ 1,000$ in initial wages is associated with an estimated 1.25 decline in the average annual growth rate of employment.

Figure 1

Initial 1982 wage levels (\$US) and subsequent employment growth, 1982-96, in the apparel sectors of 59 countries.

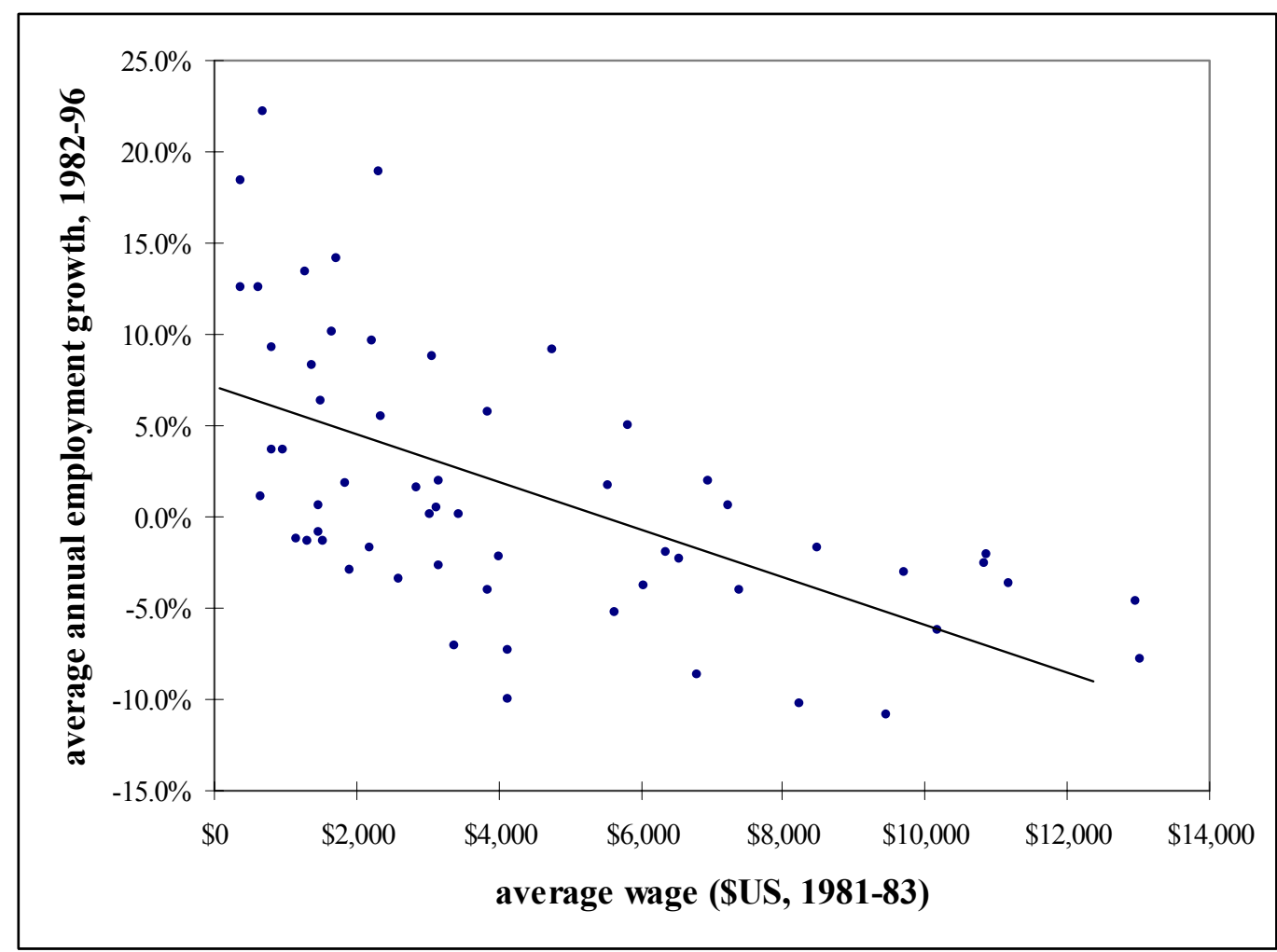

Sources: UNDIO, Industrial Statistics Database 2001. World Bank, World Development Indicators 2001.

The pattern of global clothing production appears to match the predictions of international trade theorists: countries with an abundance of low-wage labor have seen employment in their clothing sectors expand as markets have become more integrated. However, the relationships between initial wage rates and subsequent employment

4 Data are taken from the United National Industrial Development Organization (UNIDO), Industrial Statistics Database 3-digit ISIC CD-ROM 2001 and the World Bank, World Development Indicators CDROM 2001. 
growth show a great deal of variation - countries with nearly identical initial wages demonstrate very different patterns of employment growth. More importantly, the relationships in Figure 1 do not tell us whether reasonable improvements in wages and working conditions in a particular country will always lead to job losses. For example, what would happen to employment if wages (and other components of labor costs) were to gradually improve in a low-wage country?

In order to gauge to what extent changes in real wages impact employment, a panel data set covering 49 countries over the years 1981 to 1996 was assembled using the same data sources as were used to construct Figure 1. This dataset included annual measurements of employment, real wages, and real output for the apparel industries in the countries for which complete data were available. All variables were expressed in natural logarithms. Using the general method of moments (GMM) technique developed by Arellano and Bond (1991) for the estimation of dynamic panels, the following model was estimated in which employment $\left(\mathrm{E}_{\mathrm{i}, \mathrm{t}}\right)$ is expressed as a function of real wages $\left(\mathrm{w}_{\mathrm{i}, \mathrm{t}}\right)$, real output $\left(\mathrm{y}_{\mathrm{i}, \mathrm{t}}\right)$, and country-specific effects $\left(v_{\mathrm{i}}\right)$ :

$$
\mathrm{E}_{\mathrm{i}, \mathrm{t}}=\alpha+\delta \mathrm{E}_{\mathrm{i}, \mathrm{t}-\mathrm{1}}+\beta_{\mathrm{x}} \mathrm{w}_{\mathrm{i}, \mathrm{t}-\mathrm{x}}+\gamma_{\mathrm{x}} \mathrm{y}_{\mathrm{i}, \mathrm{t}-\mathrm{x}}+v_{\mathrm{i}}+\mu_{\mathrm{i}, \mathrm{t}} \text {, for } \mathrm{x}=0 \ldots 1
$$

Lags of one and two years were included for the wage and output variables. The GMM estimation for dynamic panels involves expressing the equation in first-differences. Since wages and output cannot be taken as strictly exogenous, lagged values for these variables, expressed in levels, were used as instruments in the estimation.

The results are presented in Table 1. Note that both one-step and two-step GMM estimations are presented. While the two-step procedure can achieve some efficiency gains, standard errors may be underestimated. Therefore, the one-step results can be more reliable for drawing inferences about the coefficient estimates.

What do these results imply? First, Wald tests show that the sum of the coefficients on the wage variables and the output variables are statistically significant and have the expected signs - that is, increases in real wages have a negative impact on employment while increases in real output have a positive impact. ${ }^{5}$ In interpreting the results, it is helpful to summarize the estimates in a more user-friendly fashion. For example, from these results, we can develop long-run estimates of the impact of changes in real wages and output on employment. These calculations, based on the two-step GMM procedure, are presented in Table 2. Because all variables were expressed in logarithm form, these coefficients can be interpreted as elasticity estimates.

\footnotetext{
5 For the one-step GMM estimators, the Wald test of the null hypothesis that the coefficients were not satistically different from zero yielded a test statistic for the real wage variables of $\chi^{2}(2)=75.51$ ( $p$ value $<0.001$ ) and a test statistic for the real output variables of $\chi^{2}(3)=180.53$ (p-value $\left.<0.001\right)$. The Wald test of the null hypothesis that the sum of the coefficients were equal to zero yielded a test statistics of $\chi^{2}(1)=48.96$ for real wages and $\chi^{2}(1)=74.05$ for real output. Therefore, we can reject the null hypotheses.
} 
Table 1. GMM estimates of dynamic labor demand equations for the apparel industries of 49 countries, 1981-96, $n=686$, $t$-statistics in parentheses.

\begin{tabular}{|c|c|c|c|}
\hline Variable & $\underline{\operatorname{Lag}}$ & (1) One-step & (2) Two-step \\
\hline Employment & $\mathrm{E}_{\mathrm{i}, \mathrm{t}-1}$ & $\begin{array}{l}0.6060 \\
(14.24)\end{array}$ & $\begin{array}{l}0.6073 \\
(29.41)\end{array}$ \\
\hline Real wages & $\mathrm{w}_{\mathrm{i}, \mathrm{t}}$ & $\begin{array}{r}-0.3789 \\
(-7.51)\end{array}$ & $\begin{array}{l}-0.3779 \\
(-21.01)\end{array}$ \\
\hline \multirow{3}{*}{ Real output } & $\mathrm{w}_{\mathrm{i}, \mathrm{t}-1}$ & $\begin{array}{l}0.1266 \\
(2.59)\end{array}$ & $\begin{array}{l}0.1379 \\
(16.52)\end{array}$ \\
\hline & $\mathrm{y}_{\mathrm{i}, \mathrm{t}}$ & $\begin{array}{l}0.4854 \\
(12.55)\end{array}$ & $\begin{array}{l}0.4924 \\
(51.09)\end{array}$ \\
\hline & $\mathrm{y}_{\mathrm{i}, \mathrm{t}-1}$ & $\begin{array}{l}-0.1466 \\
(-3.23)\end{array}$ & $\begin{array}{l}-0.1543 \\
(-11.93)\end{array}$ \\
\hline Constant & & $\begin{array}{l}-0.0038 \\
(-3.42)\end{array}$ & $\begin{array}{l}-0.0034 \\
(-9.79)\end{array}$ \\
\hline \multicolumn{2}{|c|}{$\begin{array}{l}\text { Wald } \chi \text {-squared (all coefficients) } \\
\text { Sargan autocorrelation test }\end{array}$} & $\begin{array}{c}1774.56 \\
-8.79 \\
(p-v a l u e<0.001)\end{array}$ & $\begin{array}{c}27684.79 \\
-2.81 \\
\text { (p-value }=0.0049\end{array}$ \\
\hline
\end{tabular}

How do we interpret these results? The long-run coefficient on real wages is 0.611 . This means that a $10 \%$ increase in real wages would be associated with a $6.1 \%$ decrease in employment, other factors remaining constant. Likewise, a $10 \%$ increase in output is associated with a $8.6 \%$ increase in employment. Therefore, holding other factors constant, including unobserved country-specific effects, an increase in real wages does appear to have a negative impact on employment in the apparel sector. However, the response is inelastic - that is, the decrease in employment is of a lesser magnitude than the increase in real wages.

These econometric estimates are based on the assumption that other factors remain constant when real wages change. What happens when other factors are allowed to change along with wages? Can wages alone explain a significant portion of the variations in the growth rate of employment in this context?

Table 2. Elasticity of labor demand estimates, long run estimates based on the results in Table 1

\begin{tabular}{|c|c|}
\hline Variable & Long-run coefficient estimate \\
\hline Real wages & -0.611 \\
\hline Real output & 0.861 \\
\hline
\end{tabular}

When we look at the simple relationship between changes in employment and changes in real wages, without controlling for other influences, we do not find a clear-cut 
relationship. Figure 2 graphs average annual changes in employment against average annual changes in real wages from 1982 to 1996. The data do not support a model that reduces the determinants of employment to a single variable - the change in the real wage rate - even for a highly globalized, labor-intensive industry such as apparel manufacturing. If other factors - such as prices, productivity, or consumer demand adjust appropriately when wages increase, space can be created to accommodate better standards without generating welfare-reducing job losses (Pollin, Burns, and Heintz 2001). ${ }^{6}$

Figure 2

Average annual \% change in real wages and employment in the apparel sector of 52 countries, 1982-96.

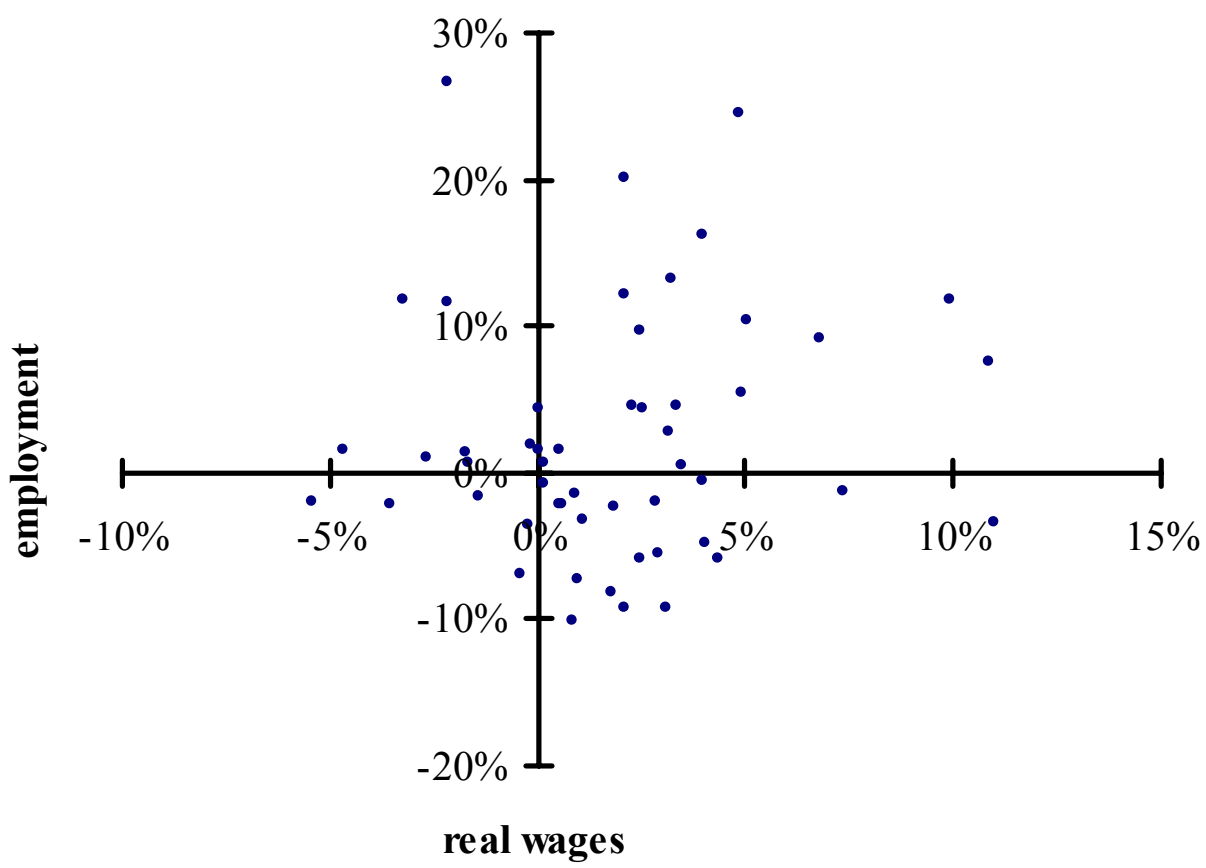

Sources: UNDIO, Industrial Statistics Database 2001. World Bank, World Development Indicators 2001.

An ILO (2000a: 43) study on the global garment and textile industries reaches similar conclusions: "Labor costs remain an important cost factor, particularly in laborintensive production such as footwear and clothing. Nevertheless ... they are no longer a decisive factor in determining competitiveness on world markets." Similarly, research into the impact of changes in the minimum wage on poverty rates in developing countries has shown that higher minimum wages reduce poverty, although the impact may not extend to very poor households that do not participate in the paid labor force (Saget 2001, Lustig and McLeod 1997). This evidence does not suggest that improvements in labor

6 Pollin, Burns, and Heintz (2001) produce a chart similar to Figure 2 covering a slightly shorter time period. They also trace a significant wage increase through the commodity chain to determine its effect on retail prices. 
standards have no impact on employment, but it casts doubt on the argument that better standards leave workers worse off on average.

To sum up: the impact of labor costs on employment cannot simply be dismissed as unimportant or trivial. However, empirical research suggests that a carefully designed system for implementing global labor standards that allows for other adjustments when labor costs increase can reduce (or possibly eliminate) the risk of job loss and can be welfare-enhancing for those workers the policies aim to help.

\section{Strategies for implementation: a brief history}

Despite the potential a system of labor standards possesses for raising the wellbeing of wage earners around the world, designing and implementing an appropriate set of institutions to realize this goal remains a significant challenge. A review of the past strategies put forward by social reformers and the consequent institutional changes that have occurred helps set the stage for a discussion of current efforts to realize a coordinated approach to labor standards.

Early support for international labor standards first emerged in the $19^{\text {th }}$ century. Advocates included Robert Owen, the Scottish industrialist and utopian thinker; Charles Hindley, a British member of parliament from 1835 to 1857; and Daniel Legrand, a prominent manufacturer from Alsace. As early as 1818, Owen was suggesting that the governments of continental Europe should implement a system of labor standards to improve conditions among Europe's working classes (Lorenz 2001: 41). Foreshadowing today's "race to the bottom" arguments, Hindley argued that international standards would prevent competitive pressures from eroding working conditions in Britain - in particular, lengthening the working day (Follows 1951). In a similar vein, Legrand promoted international labor legislation for Europe in the mid- $19^{\text {th }}$ century (Follows 1951). Legrand was strongly influenced by the Christian socialist tradition which advocated for reforming capitalism to produce humane social outcomes while condemning as heresies the demands of more radical socialist movements (Gide and Rist 1948: 514-44, Lorenz 2001: 41-4).

The work of these early proponents of international labor standards paved the way for the establishment of the International Labor Organization (ILO) in 1919 at the Versailles Peace Conference. After the turmoil of World War I, the creation of the ILO was seen as an important initiative to maintain peace, social stability, and shared prosperity in the world. ${ }^{7}$ In 1946, the ILO became the first specialized agency of the United Nations (UN) and represents the only institution created by the Treaty of Versailles to survive today. It is also the only UN agency in which non-government organizations play a large institutionalized role in formulating policy.

7 See the 1919 Constitution of the ILO, especially the Preamble, for an eloquent justification for the founding of the organization. 
The ILO operates by creating conventions that address a range of labor market policies through a process of stakeholder negotiations (in general, business, labor, and government). The ILO then attempts to persuade governments to ratify the conventions, with the understanding that ratification implies that domestic legislation will be adjusted, when necessary, to comply with the conventions. Of all the conventions developed by the ILO, eight are deemed "core conventions" covering four key areas of basic human rights: freedom of association and collective bargaining, the abolition of forced labor, the elimination of child labor, and non-discrimination.

While the ILO has had a significant impact on improving labor standards around the world, its approach has limitations. Ratification of an ILO convention does not guarantee enforcement of the standards in question. In many cases, the capacity to enforce labor laws is lacking and widespread abuses are common. In addition, membership in the ILO is not conditional on ratification of the core conventions. For example, both China and the United States have only ratified two of the eight core conventions. Finally, with the growth of multinational production systems, a strategy aimed at influencing national policy on a case-by-case basis could be misdirected. Greater capital mobility and increased subcontracting mean that individual regulatory regimes are under pressure to relax controls or risk losing job-creating investments.

In reaction to the growing internationalization of economic activity, influential global organizations began to develop corporate codes of conduct in an effort to regulate the actions of multinationals. The UN took the lead and, in 1974, established the Center on Transnational Corporations (UNCTC), which began developing a comprehensive code of conduct for multinational corporations covering many aspects of corporate behavior, including labor practices (United Nations 1986). The OECD launched its own Declaration on International Investment and Multinational Enterprises in 1976, which also set up a framework for governing corporate actions (OECD 2000). In 1977, the ILO followed suit, with its Tripartite Declaration of Principles Concerning Multinational Enterprises and Social Policy which focused more directly on labor issues (ILO 2000b).

These codes attempted to develop a universal set of standards that were to be sensitive to a country's level of development; they were meant to apply to all multinationals; and they were developed by prominent international organizations. However, not one has been implemented in a meaningful way. Despite several drafts, the UN code was never ratified and the Center on Transnational Corporations disappeared completely in 1993, having been incorporated into the United Nations Conference on Trade and Development, or UNCTAD (Jenkins 2001). While the OECD and ILO codes achieved a higher level of consensus, there was no comprehensive plan for implementation, monitoring, or enforcement. Compliance was voluntary, but the codes contained few, if any, incentives to encourage firms to change their practices.

Moreover, in the 1980s the global policy climate began to shift. Instead of questioning the behavior of multinationals, many developing nations emphasized the need to attract a growing share of foreign investment. In this context of a new neoliberal, market-oriented ideology, the ILO had trouble expanding its base of national 
governments that have ratified its more recent conventions extending protections into areas such as health and safety, let alone enforcing rules governing the behavior of multinationals (Pearson and Seyfang 2001). The ultimate outcome was that these early efforts to regulate global corporate behavior failed to deliver (Tsogas 2001: 61-2).

As these first codes of conduct faded into obscurity, there was little to replace them until the 1990s. However, growing public awareness over sweatshop practices and human rights violations among the suppliers to brand-name manufacturers prompted the development of a new type of corporate code of conduct. These new codes were created by the multinationals themselves in response to the increasingly public accusations of profit-hungry corporations turning a blind eye to labor abuses. In 1991, Levi-Strauss \& Co. became the first brand-name corporation in this new wave of social responsibility to adopt a code of conduct. Many other U.S. and European companies followed suit. Literally hundreds of different codes currently exist. Because these codes were developed with little coordination, there is an enormous amount of variation from one code to the next (Kolk, van Tulder, and Welters 1999).

These corporate codes of conduct have numerous shortcomings. First, they suffer from the "fox in the chicken coop" problem - corporations have an incentive to minimize the damage of a negative report by limiting the number of monitored suppliers or by restricting what information is made public. Second, they frequently pay scant attention to issues of implementation. Developing a code of conduct for public relations purposes receives much more attention than insuring that the standards are actually implemented. Third, because of the variation in the content of the codes, consumers find it difficult to determine what compliance with a code of conduct really means. For the producers of the goods, the existence of multiple codes increases the difficulty of compliance. Many subcontractors accept jobs from different multinationals, each with a different code of conduct (Kemp 2001). Often producers opt for the lowest common denominator and follow the codes that are easiest to implement.

In recent years, an alternative proposal for implementing global labor standards the introduction of a "social clause" into the current system of multilateral trade regulations - has created substantial controversy. The proposed policy would explicitly tie labor practices to the rules governing international trade. The social clause would allow trade sanctions to be directed at countries in which substandard labor practices exist (Caire 1994). Theoretically, a social clause would prevent countries from engaging in practices such as "social dumping" that would trigger a race to the bottom - for example, securing a competitive advantage from labor abuses or lax environmental protections. While the social clause was first framed within the context of the General Agreement on Tariffs and Trade (GATT), today's debate focuses on the World Trade Organzation (WTO), GATT's successor. Proponents argue that the WTO is the appropriate international organization for enforcing global labor standards. In a variation on this theme, others have argued that the enforcement of a social clause should be a joint responsibility of the ILO and the WTO (Ehrenberg 1996). 
The idea of a social clause has frequently been criticized for its potential to be used as a tool for disguised protectionism. Since it imposes trade sanctions on the offending country, the penalties could harm export workers in developing countries, making them worse off than they would have been without a social clause. Others have questioned whether the WTO is the appropriate institution for addressing labor standards. In particular, some have argued that introducing a social clause into the WTO would lead to inefficient negotiations, since it requires the simultaneous determination of domestic and international policies (Brown 2001). In addition, the social clause sanctions a particular state for abuses found in a transnational production chain. It is unclear whether punishments directed at the national government and industries of a particular country are always the most appropriate measures for enforcing labor standards in the context of global production.

\section{Commodity chains and global standards}

The relationship between globalized production and a system of labor standards is best understood within the context of the global commodity chain. The global commodity chain refers to the way in which the production, distribution, and sales of goods is organized across national borders. Global commodity chain analysis has been developed in the work of Gary Gereffi (1994) and others as a means of understanding the organization and influence of different players in global production systems. For example, a commodity chain for the production of a pair of sports shoes includes the subcontractor which actually assembles the shoes, the intermediary (or "jobber") which coordinates production among a network of subcontractors, the brand-name multinational which designs the shoe and builds the brand image, and the retailer which ultimately sells the shoe to the consumer.

The labor-intensive production of many consumer goods (e.g. clothing, electronics, or footwear) is often characterized by buyer-driven commodity chains in which large retailers or brand-name corporations set up and influence a decentralized system of production and distribution. ${ }^{8}$ Market power differs dramatically among the different players along the chain. The actual production is subcontracted out to small firms which generally face extremely competitive conditions (Gereffi 1994, Bonacich and Appelbaum 2000). Therefore, subcontractors cannot easily raise the price of their output without risking a loss of business. On the other hand, retailers and brand-name multinationals enjoy some degree of market power which they can use to keep prices low for the goods they purchase or to earn rents through the development of monopolistic brand identities.

Since subcontractors face intense competition, focusing adjustment strategies on these firms is likely either to fail completely or to produce the type of unintended

\footnotetext{
8 Buyer-driven commodity chains can be contrasted with producer driven commodity chains in which large industrial enterprises set up the system of global production. The relatively capital-intensive manufacture of automobiles, aircraft, and electrical machinery can be thought of as examples of producerdriven commodity chains.
} 
consequences previously discussed. However, brand-name manufacturers and large retailers could use their market power to implement improvements in labor standards at the level of production by compensating subcontractors for the cost increases. For example, they could raise retail prices modestly and pass these revenues back to finance the improvements in employment conditions. Unintended job losses would be avoided since subcontractors who complied with the standards would receive the resources necessary to implement the improvements.

A study of the possibility of financing workplace improvements in Mexico through such a scheme found that a 2-6 percent increase in the final U.S. retail price could finance a 100 percent increase in production worker wages for a variety of different garments (Pollin, Burns, and Heintz 2001). The magnitude of this price increase falls well below the amount that consumers have said they would be willing to pay to insure that their clothes are not produced under sweatshop conditions (see, for example, Elliot and Freeman 2000). Therefore, by making adjustments in the upper segments of a global commodity chain, resources can be generated for financing substantial changes in working conditions at the point of production. Furthermore, since profits of large retailers and brand-name producers depend on the careful cultivation of their brand images and corporate reputations, an association with substandard labor practices could damage profitability. Similarly, a good reputation with respect to labor standards would enhance a company's competitive position.

\section{Standardized codes of conduct for multinational commodity chains}

In a departure from other approaches to global labor standards, there has been a movement towards establishing a standardized code of conduct, with independent monitoring and enforcement, to implement labor standards across entire commodity chains. Examples of organizations embracing this approach include the Fair Labor Assocation (U.S.), the Ethical Trading Initiative (U.K.), the Clean Clothes Campaign (Europe), Social Accountability International (U.S.), and the Worker's Rights Consortium (U.S.). With these approaches, multinational firms insure that labor practices meet a common set of standards across all their suppliers. These standards include issues of health and safety, hours of work, human rights, freedom of association, wages, and discrimination. A process of independent verification through factory inspections and visits to production sites - including informal sector producers - insures that the code has been implemented. Firms that meet the basic standards can use this seal of approval in their marketing and promotion strategies. Substandard labor practices that are not corrected are publicized with the result that the reputation and brand-image of the company in question suffers.

While these independent monitoring and certification organizations avoid many of the problems associated with corporate codes of conduct, certain constraints remain. Many limit themselves to one particular market or one particular industry (e.g. the university logo market or the apparel industry). There is no universal code of conduct and substantial variations among the established codes persist. Furthermore, many rely on 
professional auditors with little or no experience with the countries and communities involved. Finally, participation is voluntary. Therefore, compliance depends to a large extent on the strength of the incentives created.

These limitations can be addressed in a number of ways. Borrowing a page from the earliest codes of conduct, a single enforcement agency to monitor multinational behavior could be housed in a well-established international organization, such as the ILO. Of course, additional resources would need to be channeled to the agency for operational support - through fees paid by member corporations, an expanded budget for the international institution, or a combination of sources. Furthermore, the enforcement agency could establish a network of NGOs, trade unions, and informal sector organizations to develop a mechanism of lodging complaints and grievances. A subset of the local non-governmental and labor organizations could also be encouraged to undergo training to serve as external auditors in the certification program. Such an arrangement would take into account relationships across the global commodity chain while providing space for influence from domestic organizations.

\section{Limitations of global labor standards}

Regardless of the implementation strategy, the limitations of any scheme along these lines to introduce global labor standards should be explicitly recognized. Most significantly, only a subset of the world's workforce would receive any benefits, since the standards are aimed at workers who produce goods for export. Workers producing nontraded goods and services would not be directly affected by interventions such as a standardized code of conduct or a social clause. In these cases, the on-going mission of the ILO to encourage states to implement and enforce better domestic standards remains invaluable. The state must retain, and indeed strengthen, its role as enforcer of standards, despite the limitations imposed by a heightened degree of global integration and interdependency.

Furthermore, adopting expansionary macroeconomic policies could prove to be a more effective strategy for improving the well-being of all workers and securing egalitarian outcomes than the enforcement of targeted labor standards. This raises the question of whether labor standards are the correct policy intervention during a period in which the growth rates of the world economy have fallen. Raising growth rates would require a coordinated move away from the austerity programs and stabilization packages of the neoliberal era and towards an expansionary alternative. Many of the protests over the consequences of raising labor standards would become irrelevant within the context of a global expansion. Most significantly, trade-offs - such as "more jobs versus better jobs" or "jobs for the North versus jobs for the South" - would no longer be binding (Singh and Zammit 2001).

However, caution must be exercised when shifting the emphasis away from labor standards and towards expansionary macroeconomic policy. While appropriate macroeconomic policies can contribute to improvements in the conditions of work, they 
might not be sufficient to wholly address the widespread erosion of the quality of employment opportunities that has been observed around the globe. For example, the process of informalization has continued apace even in economies boasting respectable levels of economic growth. This means that an increasing share of the labor force of these countries will not have access to basic social protections, despite solid records of growth. While higher levels of growth might slow the process of informalization, additional interventions will likely be needed in order to reverse the decline in social protection (Heintz and Pollin 2002).

Of course, posing the issue as a choice between changes in the macroeconomic policy regime or the implementation of a system of global standards unduly limits the options available. The two strategies are not necessarily mutually exclusive. A coordinated approach involving a range of interventions - both macroeconomic and in terms of targeted international regulations - would be the most effective means of improving economic outcomes for individuals engaged in paid labor worldwide.

\section{Conclusions}

Despite the limitations of global labor standards, the potential that such interventions have for improving the working lives of a significant number of people should not be underestimated. Furthermore, the possible impact of such a system extends well beyond the benefits generated by its core policies. The development of an appropriate regulatory scheme for enforcing basic standards of decency could serve as a model for governing multinational economic activities more generally. Because of these possible contributions, striving to create an effective framework for global labor standards represents an important policy goal in this era of internationalized production and consumption.

\section{References}

Alston, Philip (1996), “Labor rights provisions in U.S. trade law: ‘aggressive unilateralism’?” In L. Compa and S. Diamond, eds. Human Rights, Labor Rights, and International Trade, Philadelphia: University of Pennsylvania Press, pp. 71-95.

Amsden, Alice (1997), “International labor standards: hype or help?” The Boston Review, 20(6).

(1994), "Macro-sweating policies and labour standards," In W. Sengenberger and D. Campbell, eds. International Labour Standards and Economic Interdependence, Geneva: International Institute for Labour Studies (ILO), pp. 185-93.

Arellano, Arellano and Bond, Stephen (1991) "Some tests of specification for panel data: Monte Carlo evidence and an application to employment equations," Review of Economic Studies, 58: 277-97.

Basu, Kaushik (1999) “Child labor: cause, consequence, and cure, with remarks on international labor standards,” Journal of Economic Literature, 37(September): 1083-119. 
Benería, Lourdes (2001), "Shifting the risk: new employment patterns, informalization, and women's work," International Journal of Politics, Culture, and Society 15(1): 27-53.

(1991), "Structural adjustment, the labour market, and the household: the case of Mexico," In G. Standing and V. Tokman, eds. Towards Social Adjustment: labour market issues in structural adjustment, Geneva: ILO, pp. 161-83.

Bhagwati, Jagdish (2002), Free Trade Today, Princeton, NJ: Princeton University Press.

(1995), "Trade liberalization and 'fair trade' demands: addressing the environmental and labour standards issues," World Economy 18(6): 745-59.

Bonacich, Edna and Appelbaum, Richard (2000), Behind the Label: inequality in the Los Angles apparel industry, Berkeley, CA: University of California Press.

Braunstein, Elissa (2002), "Gender, FDI, and women's autonomy: a research note on empirical analysis," Paper presented at the conference on Global Labor Standards and Living Wages, Political Economy Research Institute, University of Massachusetts, April 19-20.

Brown, Drusilla (2001), "Labor standards: where do they belong on the international trade agenda?" Journal of Economic Perspectives, 15(3): 89-112.

Brown, Drusilla, Deardorff, Alan, and Stern, Robert (1997), "International labor standards and trade: a theoretical analysis," In J. Bhagwati and R. Hudec, eds. Fair Trade and Harmonization: prerequisites for free trade? Vol. 1, Cambridge, MA: The MIT Press, pp. 227-80.

Bowles, Samuel and Boyer, Robert (1995), "Wages, aggregate demand, and employment in an open economy: an empirical investigation," In G. Epstein and H. Gintis, eds. Macroeconomic Policy After the Conservative Era, Cambridge, UK: Cambridge University Press, pp. 143-171.

Buchele, Robert and Christensen, Jens (1995), "Productivity, real wages, and workers' rights: a crossnational comparison," Labour 9(3): 405-22.

Caire, Guy (1994), "Labour standards and international trade," In W. Sengenberger and D. Campbell, eds. International Labour Standards and Economic Interdependence, Geneva: International Institute for Labour Studies (ILO), pp. 297-317.

Charmes, Jacques (2000), "Informal sector, poverty, and gender: a review of empirical evidence," Background paper prepared for the World Development Report 2001, World Bank.

Corden, W. Max and Vousden, Neil (2001), "Paved with good intentions: social dumping and raising labour standards in developing countries," In Z. Drabek, ed. Globalization Under Threat: the stability of trade policy and multilateral agreements, Cheltenham, UK: Edward Elgar, pp. 124-43.

Ehrenberg, Daniel (1996), "From intention to action: an ILO-GATT/WTO enforcement regime for international labor rights," In L. Compa and S. Diamond, eds. Human Rights, Labor Rights, and International Trade, Philadelphia: University of Pennsylvania Press, pp. 163-180.

Elliott, Kimberly and Freeman, Richard (2000), "White hats or Don Quixotes? Human rights vigilantes in the global economy," National Bureau of Economic Research Conference on Emerging Labor Market Institutions, August.

Elson, Diane (1996), “Appraising recent developments in the world market for nimble fingers," In A. Chhachhi and R. Pittin, eds. Confronting State, Capital, and Patriarchy: women organizing in the process of industrialization, New York: St. Martin's Press, pp. 35-55. 
Fussell, Elisabeth (2000) "Making labor flexible: the recomposition of Tijuana's maquiladora female labor force," Feminist Economics 6(3): 59-80.

Gereffi, Gary (1994), "The organization of buyer-driven global commodity chains: how U.S. retailers shape overseas production networks," In G. Gereffi and M. Korzeniewicz, eds. Commodity Chains and Global Capitalism, Westport, CT: Greenwood Press, pp. 95-122.

Gide, Charles and Rist, Charles (1948), A History of Economic Doctrines From the Time of the Physiocrats to the Present Day, $2^{\text {nd }}$ ed., trans. R. Richards, Boston: D.C. Heath and Co.

Goldstein, Arthur, Veum, Jonathan, and Darity, William (2000), "Working hard for the money? Efficiency wages and worker effort," Journal of Economic Psychology 21(4): 351-85.

Heintz, James and Pollin, Robert (2002), "Informalization, economic growth and the challenge of creating viable labor standards in developing countries," Paper presented at the conference Rethinking Labor Marker Informalization: precarious jobs, poverty, and social protection, Cornell University, October 18-19, 2002, http://www.einaudi.cornell.edu/GenderGlobalChange/.

Huang, Tzu-Ling, Hallman, Arne, Orazem, Peter, and Paterno, Elizabeth (1998), "Empirical tests of efficiency wage models," Economica 64: 125-43.

ILO (2002) Decent Work and the Informal Economy, Report VI presented at the $90^{\text {th }}$ session of the International Labor Conference, Geneva: International Labor Office.

ILO (2001) World Employment Report 2001. Geneva: International Labor Organization.

ILO. (2000a). Labour Practices in the Footwear, Leather, Textile, and Clothing Industries. Geneva: International Labor Organization.

ILO. (2000b). "Tripartite Declaration of Principles Concerning Multinational Enterprises and Social Policy.” Document: (OB Vol. LXXXIII, 2000, Series A, No. 3).

Jenkins, Rhys (2001), “Corporate codes of conduct: self-regulation in a global economy,” Technology, Business, and Society Paper, No. 2, United Nations Research Institute for Social Development (UNRISD).

Joekes, Susan (1987), Women in the World Economy, Oxford, UK: Oxford University Press.

Kabeer, Naila (2000), The Power to Choose: Bangladeshi women and labour market decisions in London and Dhaka, London, New York: Verso.

Kemp, Melody (2001), "Corporate social responsibility in Indonesia. Quixotic dream or confident expectation?" Technology, Business, and Society Programme Paper No. 6, United Nations Research Institute for Social Development (UNRISD).

Khattak, Saba Gul (2002), "Subcontracted work and gender relations: the case of Pakistan," In R. Balakrishnan, ed. The Hidden Assembly Line: gender dynamics of subcontracter work in a global economy, Bloomfield, CT: Kumarian Press, pp. 35-61.

Kolk, Ans, van Tulder, Rob, and Welters, Carlijn (1999), "International codes of conduct and corporate social responsibility: can transnational corporations regulate themselves?" Transnational Corporations, 8(1), 143-180.

Kristof, Nicholas (2002), “Let them sweat,” New York Times (June 25).

Krugman, Paul (1998), The Accidental Theorist, New York: Norton. 
Levine, David (1992), "Can wage increases pay for themselves? Tests with a production function," Economic Journal. 102(414): 1102-15.

Lim, Linda (1983), "Capitalism, imperialism, and patriarchy: the dilemma of third-world women workers in multinational factories," In J. Nash and M. Fernández-Kelly, eds. Women, Men, and the International Division of Labor, Albany, NY: SUNY Press, pp. 70-91.

Lorenz, Edward (2001), Defining Global Justice: the history of U.S. international labor standards policy, Notre Dame, IN: Notre Dame University Press.

Lustig, Nora and McLeod, Darryl (1997), "Minimum wages and poverty in developing countries: some empirical evidence," In S. Edwards and N. Lustig, eds. Labor Markets in Latin America: combining social protection with market flexibility, Washingto, DC: Brookings Institution Press, pp. 62-103.

Majid, Nomaan (2001), “The working poor in developing countries," International Labour Review, 140(3): $271-91$.

Marshall, Ray (1994), "The importance of international labour standards in a more competitive global economy," In W. Sengenberger and D. Campbell, eds. International Labour Standards and Economic Interdependence, Geneva: International Institute for Labour Studies (ILO), pp. 65-78.

OECD. (2000), "The OECD declaration and decisions on international investment and multinational enterprises: basic texts," DAFFE/IME(2000)20.

Palley, Thomas, Drake, Elizabeth, and Lee, Thea (1999), "The case for core labor standards in the international economy: theory, evidence, and a blueprint for implementation," AFL-CIO Economic Policy Papers, No. E041.

Pearson, Ruth and Seyfang, Gill (2001), "New hope or false dawn? Voluntary codes of conduct, labor regulation, and social policy in a globalizing world," Global Social Policy. 1(1):49-78.

Polanyi, Karl (1957), “Aristotle discovers the economy,” In K. Polanyi, C. Arensberg, and H. Pearson, eds. Trade and Market in the Early Empires, New York: The Free Press, pp. 64-94.

(1944), The Great Transformation: the political and economic origins of our time, Boston: Beacon Press.

Pollin, Robert, Burns, Justine, and Heintz, James (2001), “Global Apparel Production and Sweatshop Labor: Can Raising Retail Prices Finance Living Wages?” Political Economy Research Institute Working Paper No. 19, University of Massachusetts.

Reddy, Sanjay and Pogge, Thomas (2002), "How not to count the poor," Mimeo, Depts. of Economics and Philosophy, Columbia University.

Rodrik, Dani (1996). "Labor standards in international trade: do they matter and what do we do about them?" In R. Lawrence, D. Rodrik, and J. Walley, Emerging Agenda For Global Trade: High Stakes for Developing Countries. Washington, D.C.: Overseas Development Council, pp. 35-79.

Roldan, Martha (1988), "Renegotiating the marital contract: intrahousehold patterns of money allocation and women's subordination among domestic outworkers in Mexico City," In D. Dwyer and J. Bruce, eds. A House Divided: women and income in the Third World, Stanford, CA: Stanford University Press, pp.229-247. 
Saget, Catherine (2001), "Poverty reduction and decent work in developing countries: do minimum wages help?" International Labour Review, 140(3): 237-69.

Sathar, Zeba and Kazi, Shahnaz (1989), "Female employment and fertility: further investigation of an ambivalent association," The Pakistan Development Review, 28(3): 175-94.

Seguino, Stephanie (2000), "The effects of structural change and economic liberalization on gender wage differentials in South Korea and Taiwan," Cambridge Journal of Economics 24(4): 437-59.

Sen, Amartya (1990), “Gender and cooperative conflicts," In I. Tinker, ed. Persistent Inequalities: women and world development, Oxford, UK: Oxford University Press, pp. 123-49.

Sengenberger, Werner (1994), "International labour standards in a globalized economy: the issues," In W. Sengenberger and D. Campbell, eds. International Labour Standards and Economic Interdependence, Geneva: International Institute for Labour Studies (ILO), pp. 3-15.

Shapiro, Carl and Stiglitz, Joseph (1984), "Equilibrium unemployment as a worker discipline devise," American Economic Review, 74(3): 433-44.

Singh, Ajit and Zammit, Ann (2000), The Global Labour Standards Controversy: critical issues for developing countries, Geneva: The South Centre.

Standing, Guy (1999), Global Labour Flexibility: seeking distributive justice, New York: St. Martin's Press.

(1989), “Global feminization through flexible labor," World Development, 17(7): 1077-95.

Stanford, Jim (1998), "Openness and equity: regulating labor market outcomes in a globalized economy," In D. Baker, G. Epstein, and R. Pollin, eds. Globalization and Progressive Economic Policy, Cambridge, U.K.: Cambridge University Press, pp. 245-270.

Tsogas, George (2001), Labor Regulation in a Global Economy, Armonk, NY: M.E. Sharpe, p. 61-2.

United Nations (1986) "The United Nations code of conduct on transnational corporations," UNCTC Current Studies, Series A, No. 4, September.

Vandemoortele, Jan (1991) "Labour market informalization in sub-Saharan Africa," In G. Standing and V. Tokman, eds. Towards Social Adjustment: labour market issues in structural adjustment, Geneva: ILO, pp. 81-113. 